\title{
KADAR MEAN CORPUSCULAR VOLUME (MCV) PADA PENGGUNA ALKOHOL MENAHUN DI DESA RURUKAN KECAMATAN TOMOHON TIMUR
}

\author{
${ }^{1}$ Nanang A. Mokoagow \\ ${ }^{2}$ Siantan Supit \\ ${ }^{2}$ Hedison Polii \\ ${ }^{1}$ Kandidat Skripsi Fakultas Kedokteran Universitas Sam Ratulangi Manado \\ ${ }^{2}$ Bagian Fisiologi Fakultas Kedokteran Universitas Sam Ratulangi Manado \\ Email: andryana034@gmail.com
}

\begin{abstract}
Chronic consumption of alcohol in large enough quantity can cause a variety of health problems, one of them is anemia. Maximum blood alcohol level is achieved in 30-90 minutes. This study aimed to obtain the level of Mean Corpuscular Volume (MCV) among alcohol consumers in Rurukan village, Tomohon. This was a descriptive study with a cross sectional design. The level of MCV was measured by using ABX tool Petra XL 80. The results showed that there were 30 respondents in this study. Most of the respondents were in age group 46-55 years (63\%), worked as labours/motor drivers $(80 \%)$, and the durations of alcohol consumption were 7-10 years and 11-15 years with an average of MCV level of 88.62 $\mathrm{fL}$ (within normal limit). Conclusion: The average of MCV level of chronic alcohol consumers in Rurukan village, Tomohon, was still within normal limit.
\end{abstract}

Keywords: chronic alcohol consumption, MCV

\begin{abstract}
Abstrak: Penggunaan alkohol yang lama dan dalam jumlah cukup besar dapat menimbulkan berbagai masalah kesehatan, salah satunya anemia. Kadar alkohol maksimum dalam darah dicapai 30-90 menit. Penelitian ini bertujuan untuk mengetahui gambaran kadar MCV pada pengguna alkohol menahun di Desa Rurukan Kecamatan Tomohon Timur. Penelitian ini bersifat deskriptif dengan rancangan potong lintang. Pemeriksaan kadar MCV menggunakan alat BAX Petra XL 80. Hasil penelitian memperlihatkan dari 30 responden yang terbanyak terdapat pada kelompok umur 46-55 tahun (63\%), pekerjaan sebagai buruh/ojek (80\%), dan lama mengonsumsi alkohol 7-10 tahun dan 11-15 tahun dengan rerata kadar MCV 88,62 fL (dalam batas normal). Simpulan: Rerata kadar MCV pengguna alkohol menahun di Desa Rurukan Kecamatan Tomohon Timur masih dalam batas normal.
\end{abstract}

Kata kunci: konsumsi alkohol menahun, MCV

Salah satu bahan kimia yang dapat memengaruhi sistem saraf pusat (SSP), menghilangkan penderitaan fisik dan mental atau menghasilkan euphoria ialah alkohol. Bahan ini diperoleh dari peragian/fermentasi madu, sari buah atau umbi-umbian. Dari peragian tersebut dapat diperoleh alkohol sampai $15 \%$. $^{1,2}$

Kadar alkohol dalam darah maksimum dicapai 30-90 menit. Setelah diserap, alkohol/etanol disebarluaskan ke seluruh jaringan dan cairan tubuh. Dengan peningkatan kadar alkohol dalam darah orang akan menjadi euforia, namun dengan penurunan kadarnya orang tersebut menjadi depresi. ${ }^{3}$

Alkohol dapat mennghasilkan efek ganda pada tubuh: 1) efek depresan yang singkat; 2) efek pada susunan saraf pusat yang berlangsung 6 kali lebih lama dari 
efek depresannya. Kesadaran atas kedua efek ini sangat bergantung pada kondisi susunan saraf pusat pada saat penggunaan alkohol berlangsung. Dengan demikian efek penggunan alkohol juga tergantung pada lingkungan, penggunaan, dan kepribadian orang yang bersangkutan. ${ }^{4}$

Berdasarkan Keppres No. 3 Tahun 1997 tentang pengawasan dan pengendalian minuman beralkohol dibagi dalam tiga golongan: Golongan A: kadar etanol 1-5\%; Golongan B: kadar etanol 520\%; dan golongan C: kadar etanol 20$55 \% .^{5}$

Mean corpuscular volume (MCV) adalah volume korpuskular rata-rata, yaitu ukuran dari volum eritrosit. Rentang MCV normal ditetapkan sebesar 80-100 fL. Nilai MCV yang tinggi dikaitkan dengan alkoholisme. ${ }^{6,7}$

Pecandu berat alkohol sering mengalami peningkatan ringan nilai MCV (100-110 fL). Penyebab peningkatan MCV masih belum jelas, tetapi terdapat hubungan antara derajat peningkatan MCV dan jumlah konsumsi alkohol. Peningkatan ini akan menurun dengan perlahan (2-4 bulan) setelah penghentian asupan alkohol. ${ }^{8}$

Alkohol bekerja pada sistem saraf pusat. Konsumsi alkohol berefek sedasi dan antiansietas, dan pada kadar yang lebih tinggi dapat menimbulkan adanya efek stimulasi sistem saraf pusat. Konsumsi alkohol secara kronis dapat menyebabkan gangguan mental dan neurologis yang berat berupa hilangnya ingatan dan gangguan tidur. Alkohol dosis sedang menimbulkan vasodilatasi pembuluh darah sedangkan penggunaan alkohol belebihan jangka panjang menyebabkan kerusakan jantung menetap. ${ }^{9}$

\section{METODE PENELITIAN}

Penelitian ini bersifat deskriptif dengan menggunakan desain potong lintang. Penelitian ini dilaksanakan di Desa Rurukan Kecamatan Tomohon Timur. Populasi dan sampel penelitian ialah subjek berusia produktif yang mengonsumsi alkohol berdasarkan kriteria inklusi yaitu umur 20-55 tahun, telah mengonsumsi alkohol selama 5 tahun dengan frekuensi minimal seminggu 3 kali.

\section{HASIL PENELITIAN DAN BAHASAN}

Pada penelitian ini diperoleh 30 orang responden. Tabel 1 memperlihatkan responden terbanyak menurut kelompok umur terdapat pada kelompok umur 46-55 tahun sebesar $63 \%$.

Tabel 1. Distribusi Responden Menurut Kelompok Umur

\begin{tabular}{ccc}
\hline Umur (tahun) & $\mathrm{N}$ & $\%$ \\
\hline $25-35$ & 8 & 17 \\
$36-45$ & 10 & 20 \\
$46-55$ & 12 & 63 \\
Total & 30 & 100 \\
\hline
\end{tabular}

Tabel 2 menunjukkan distribusi responden terbanyak dari kelompok pekerjaan ialah dari kelompok buruh/ojek dengan jumlah $80 \%$.

Tabel 2. Distribusi Responden Menurut Jenis pekerjaan

\begin{tabular}{ccc}
\hline JenisPekerjaan & $\mathrm{N}$ & $\%$ \\
\hline Petani & 18 & 72 \\
Ojek/buruh & 10 & 80 \\
PNS/Pensiunan PNS & 2 & 8 \\
Total & 30 & 100 \\
\hline
\end{tabular}

Tabel 3 menunjukkan distribusi responden berdasarkan lama konsumsi alkohol yang terbanyak ialah 7-10 tahun dan 11-15 tahun dan kadar MCV responden masih dalam batas normal yakni 89,25\%

Tabel 3. Distribusi Responden Berdasarkan Lama Konsumsi Alkohol

\begin{tabular}{ccc}
\hline $\begin{array}{c}\text { Lama konsumsi } \\
\text { alkohol (thn) }\end{array}$ & N & $\begin{array}{c}\text { Rerata } \\
\text { MCV }\end{array}$ \\
\hline $7-10$ & 6 & 88 \\
$11-15$ & 6 & 88 \\
$16-20$ & 4 & 88,75 \\
$21-25$ & 5 & 86,2 \\
$26-30$ & 5 & 87,4 \\
$31-35$ & 4 & 89,25 \\
\hline
\end{tabular}


Tabel 4. Distribusi responden berdasarkan nilai rerata $\mathrm{MCV}$

\begin{tabular}{ccc}
\hline Nilai rerata & $\begin{array}{c}\text { Nilai } \\
\text { tertinggi }\end{array}$ & $\begin{array}{c}\text { Nilai } \\
\text { terendah }\end{array}$ \\
\hline 86,62 & 100 & 82 \\
\hline
\end{tabular}

Faktor yang menyebabkan responden mengonsumsi alkohol ialah karena pergaulan dan keinginan sendiri. Selain itu di Desa Rurukan terdapat beberapa tempat produksi alkohol tradisional. Jenis minuman yang terbanyak dikonsumsi masyarakat Desa Rurukan ialah jenis cap tikus. Cap tikus ialah minuman beralkohol tradisional yang menjadi ciri khas masyarakat Sulawesi Utara. Cap tikus dihasilkan dari proses penyulingan air nira, mengandung kadar alkohol cukup tinggi dan termasuk dalam alkohol golongan C dengan kadar etanol 20-55\%.

Dari hasil survei dengan menggunakan kuesioner, rata-rata responden mengonsumsi alkohol 1-3 kali dalam seminggu dengan frekueensi lebih dari 5 tahun. Dalam penelitian ini, gambaran hasil penelitian rerata kadar MCV responden masih dalam nilai normal yakni 88,62 fL.

\section{SIMPULAN}

Dari hasil penelitian di Desa Rurukan Kecamatan Tomohon Timur dapat disimpulkan bahwa rerata kadar MCV pengguna alkohol menahun masih dalam batas normal yakni 88,62 fL.

\section{DAFTAR PUSTAKA}

1. Davidson GC, Neal JM, Kring AM. Gangguan yang berkaitan dengan penggunaan zat. In: Psikologi Abnormal (Edisi 9). Jakarta: Raya Grafindo Persada, 2012; p. 497.
2. Lisa JFR, Sutrisna NW. Narkoba Psikotoprika dan Gangguan Jiwa Tinjauan Kesehatan dan Hukum. Jogjakarta: Medikal Book. 2013: 22

3. Alkohol. [homepage on the Internet]. Nodate [cited 06 Feb 2014]. Available from: http://kevinzihan29.w0rdpress.com/

4. Pedoman Penatalaksanaan Medik Gangguan Penggunaan NAPZA [homepage on the Internet]. Nodate [cited 06 Feb 2014]. Available from: http://www.scribd.com/doc/196084248/ kep-menkes-422/SK/III/2010

5. Pengawasan dan Pengendalian minuman beralkohol [homepage on the Internet]. Nodate [cited 06 Feb 2014]. Available from:

http//www.hukum.unsrat.ac.id/pre/kepp res/03/1977

6. Mean Corpuscular Volume [homepage on the Internet]. Nodate [cited 06 Feb 2014]. Available from: http://www.kamuskesehatan.com/arti/m $\mathrm{cr}$

7. Mean Corpuscular Volume-wikipedia, the free encyclopedia. [homepage on the Internet]. Nodate [cited 06 Feb 2014]. Available from: en.wikipedia.org/wiki/mean_corpuscula r_volume.

8. Waterbury L. Anemia dengan MCV Tinggi. In: Buku Saku Hematologi [homepage on the Internet]. Nodate [cited 06 Feb 2014]. Available from: http://books.googlr.co.id/books?id=QwNo9REK60C\&PG=PA25\&Ipg=PA 26\&ots=WoePbKzss\&focus=viewport \&dq=hubungan+anemia+dengan+alkoh ol\&hl=id\&output=html-text

9. Wiria MSS. Hipnotik sedative dan alcohol. In: Gunawan SG, Setiabudy R, Nafriadi, Elizabet. Farmakologi Dan Terapi (Edisi 5). Jakarta: FKUI, 2007; p. 157-8. 